\title{
The Centrality of the Social in African Farming
}

James Fairhead and Melissa Leach

\section{Introduction}

There is a tendency when examining African agriculture to speak about "the farmer", their "farm", their "farming system", or "the farming community", and to understand the unfolding of African farming in relation to factors shaping these. Yet for more than a century, researchers working with African farmers have found this vocabulary unhelpful because they generate an image of farming which is divorced from the social relations of those who do it. In this article, we recall some of the central themes of these literatures, and reflect on their renewed importance as African farming encounters regenerating interest in African agriculture within a rapidly transforming global agrarian order.

These literatures explore the social shaping of African farming from the most intimate domains of intra-household arguments to the most international, tracing the footprint in farming of global trade and travel. The literatures of the last few decades on gender and agriculture, showing the gendered relations of farming practices (e.g. Dey 1981; Guyer 1986), and on the social dimensions of resource access and control between different political communities (e.g. Bassett 1993), themselves draw on much earlier traditions of analysis, whether stemming from Marxist political economy or the real day-to-day dilemmas faced by colonial administrators. Equally, the literatures showcasing farmers' know-how and its discerning logic not only within technical but also within moral and cultural orders (Fairhead 1992a) have roots in early anthropological inquiry into African social worlds (Richards 1939), and the observations of certain colonial agronomists who were as much apprentice to as administrators of those they worked with. As these issues are the stuff of rural society, they have long featured strongly in African fiction (Achebe 1996) and African anti-colonial and post-colonial writings (Kenyatta 1965; Amanor 1994).
Neither agricultural production and investment, the technologies employed in this, nor the operation of agricultural markets, can be understood outside of these social and cultural relations. Here we aim to illustrate this, and show the poverty of analytical frames that ignore them, and the impoverishment they would lead to. The new century brings revolutions in communication technology, biotechnology and mobility, and heightened challenges in health and a transforming and hostile global trading order. Yet in as much as these are new, they merely heighten the importance of understanding African farming in social relational terms, with older literatures becoming more, not less, pertinent in assessing agricultural development opportunities.

\section{The social shaping of agricultural production and investment}

The literature on gender and agriculture in Africa has explored the reasons behind what is farmed, being usually the outcome of negotiation sometimes fraught - between husbands and wives, between co-wives, and between them and their children. Rather than see the crops in any field as reflecting the economic calculus of "the farmer", or "the farm household", this literature discerns how different interests and priorities are reflected in it. Which priorities prevail reveals the differential power in control over land, labour and investments, which are not simply about ownership but also about notions of gendered and gerontocratic responsibility.

For example in intercropping, which is such a predominant feature of smallholder farming in Africa, rights and responsibilities for each component can be different. Taking the example of the common coffee and bean intercrop of

IDS Bulletin Vol 36 No 2 June 2005 @ Institute of Development Studies 
highland central Africa, the coffee tends to be controlled by men and the beans by women. In the upland rice fields of West Africa, the rice tends to be controlled by the men and senior wives responsible for household provisioning, and the large variety of vegetable intercrops by co-wives and daughters for their own food and income needs. In each case, the composition of the intercrop and its production process is shaped by negotiations over space, planting and weeding labour. How this works out for different farm families may be different even among neighbours, given the particular tenor of conjugal and co-wife relations, and the ways these are shaped by wider family, community and extra-community connections. And what is true for intercrops is equally the case for the choice of crops between fields and over seasons.

As Richards (1989) has portrayed it, African agriculture is as much an unfolding improvisation as it is the carrying-through of a predefined plan or system. Over a farming season the unpredicted events in the ecological and social world that can be so important for smallholder farming (perhaps in contrast with large-scale farming enterprises) intervenes and must be responded to, provoking new negotiations and adjustments.

These intra-household and improvisational analytical framings are all the more important today in tracing the impact on agricultural production and development opportunities of transnational migration and remittances, of mobile phone technology, of shifts in household abilities and responsibilities linked to HIV, AIDS, and other illnesses, of new biotechnologies, or new market opportunities linked to global trade.

These analytical perspectives lead agricultural research and development into the privacy of every household, and potentially into the instrumentalisation of its findings. Their critics, both radical and conservative, have questioned how far state and international policy should extend into such intimate and culturally sensitive issues. Yet such critics play into the naiveté of technocentric and economistic reasoning. A myriad of examples shows how gender-blind (and socially blind) approaches are not neutral, but frequently either play into existing social relations to increase inequalities, or simply fail as they are sociotechnically inappropriate (Boserup 1970).

Given the embeddedness of farming in social relations, it should come as no surprise that farmers invest in these. As Berry (1993) has emphasised, when farmers plough returns from their cropping into expenditures on weddings, funerals, initiation ceremonies or beer parties; or give away to kin resources that might have been spent on seed or soil conservation, they are securing the social support necessary for their place in the community, successful negotiations for land or labour, or the ability to call for help in hard times. Investment in social relations is investment in agriculture.

The social and power relations that are exemplified in these micro-studies have been dubbed a political ecology. What is true for the micro can also be recognised on a larger scale, and in ways that intersect with these local processes. Thus, for example, the persistent tensions that are often observed between farmers and "herders" in West Africa often hinge on access to particular resources that each group values differently, and while they might be resolved through payments akin to the market, there are alternative patterns of resolution through political and historical resource claims (Bassett 1993). In such instances, it is all too clear how national political discourse and struggles interplay with these tensions, as politicians have garnered rural support from and in turn supported differently placed constituencies, helping forge links between occupational and social identities. It is equally, but often less visibly, the case that national political processes interplay with the gendered and generational political ecology of resource use.

The prevalence of armed conflict in many parts of rural Africa should serve as a reminder that resource allocation must be understood in politicaleconomic terms, in which the unfolding of economic opportunity is intimately connected with the unfolding of political constituency. Thus any attempt to configure agriculture as simply technical, or a matter of getting the economic incentives right, can obfuscate the issues that are central to rural people's lives and concerns.

\section{The social shaping of technical knowledge}

A great deal of research attention has been paid to farmers' technical know-how across Africa, whether couched rather statically in terms of traditional or indigenous knowledge, or more dynamically in the interplay of local knowledges with those of the agricultural, educational and scientific establishments. While work on the former that 
drew a strong contrast between indigenous knowledges and Western science imagined a development encounter that combined the strengths of each (Brokensha et al. 1980; Chambers et al. 1989), the latter research tradition has led to an appreciation of the relations between knowledge, social and cultural orders and power.

Research in this vein appreciates that the research methods, concepts and assumptions on which modern agricultural science is grounded have been conditioned not only by the particular ecological contexts in which it arose, but also by the particular social and economic contexts in which it has developed. Assumptions embedded in the world of commercial agriculture can be challenged by those for whom farming is embedded in very different ways of life, and especially where farming practices have moral as well as technical dimensions. For example, assessing soil fertility through the calculus of nutrients in which fertility status is understood as if it were a bank account, as the nutrient balance models in soil science now do, is challenged by those who have a wider social calculus on the determinants of soil and site fertility (Scoones 2001). For example, soil fertility is at times understood as determined primarily by marshalling the labour needed to enable the necessary investments; by the orchestration of irrigation water; by the social orchestration of crop and irrigation timing, or by proper household relations that ensure the social complementarity that leads to successful crop production (e.g. Jacobson-Widding and van Beek 1990; Moore et al. 1999). Thus a crisis in soil fertility may be a crisis in labour, a crisis in morality, or a crisis in investment, rather than a crisis in soils per se.

While agronomists might counter that these are superstition-based frameworks and that the nutrient balance is a more objective view, this presupposes that soil fertility should be understood as separate from the social, economic and moral systems in which soils are used. It treats soil fertility simply as if it were a capital reserve that can be drawn down, added to, and transferred between accounts. Viewed thus, both the soil and its fertility are treated as commodities. This understanding of soil and its fertility is compatible with neoliberal ideas of the market, land markets and of traded inorganic fertiliser. Indeed, conceiving of fertility in this way helps make the social and economic assumptions of capitalist agriculture appear to be natural, and extends and embeds these views in wider society.
Yet, it does not necessarily reflect the way that many African farmers consider soil and its fertility and hence think about and act in relation to external agronomic and economic interventions.

New agricultural technologies, and now new generations of biotechnology, are thus not simply alternative technical solutions to technical farming problems. Rather, each carries implications for social and moral relations, and their appropriateness who might value them - depends upon these issues. Furthermore, many of today's technologies, produced at great distance in global or corporate centres of power, carry new implications for relations of economic and political dependency. Farmers are likely to judge their acceptability in ways that draw both on local social and moral discourses and on political imaginaries of the global and corporate world, as well as on past experiences of regimes of techno-governance.

\section{The social shaping of agricultural marketing}

A third arena of social research related to African agriculture has turned on the marketing of agricultural products.

Economic policies around agricultural marketing have regularly been driven by an ideological view of the market, whether inflected more by neoclassical economic ideas or by neo-revolutionary thought. The former has spawned the liberalised market-based approaches of structural adjustment programmes, and the latter the market-defence approaches in which producers are encouraged to form cooperatives, or groups. In the first case, the empirical study of trading practices has consistently shown how far trade liberalisation has overlooked the way markets are controlled and socially and politically embedded. It was soon recognised, for example, how the informal economies that came for a time in the 1980s to dominate policy discourse as the nuclei of entrepreneurship were themselves regulated by informal polities whether the ethnic cartels of Nairobi, or the protection racketeering of the Democratic Republic of the Congo. When the state "rolled back" under the structural adjustment liberalisation, more informal polities rolled in. New trading dynamics emerged. Thus in Congo, women were for a time able to avoid the expropriation of products on the way to market that beset men, and thus men began to "hide behind women", entrusting them to carry their products to market. What might 
have been read as an invigoration of women's trading activity in a context of liberalisation was in reality a renegotiation of gendered labour arrangements in which women were transporting products with little control over the revenue (Newbury and Schoepf 1989; Fairhead 1992b).

In the second case, empirical study of the cooperative movements designed to address exploitative trading relations have demonstrated how these have often been understood as the latest in a long line of forced social organisation and appropriation, whether dating back to colonial or state socialist eras. Equally the relationships with traders that such approaches are designed to replace were often, in reality, more embedded in and regulated by the social world to which traders also belonged. In Sierra Leone, for example, rice traders were involved in long-term patron-client relations with farmers which also involved other forms of exchange of financial and labour resources, and sometimes political support (Richards 1986).

These empirical studies thus claim to portray the operation of "real markets" as embedded in social and political institutions (de Alcantara 1992), as distinct from the ways markets are assumed to operate in policy discourses. A further dimension of this literature has explored the ways that forms of exchange are understood in cultural terms, and evaluated within moral orders. Thus, among the Luo in Kenya, land could be exchanged for money between kin, but outside kinship relations this was considered immoral (Shipton 1989). Such cases highlight what might be termed indigenous economic knowledge, and suggest its importance in shaping how farmers might respond to new marketing interventions.

Emerging largely in the 1980s era of structural adjustment, the spate of work on real markets has focused mainly on how the socio-cultural dynamics of local trade have intersected with state processes. A challenge now is to scale up these perspectives to analyse how farmers are engaging with and reflecting on new opportunities in global trade and the social implications of these engagements.

\section{Conclusions}

The research on the social dimensions of African farming that we have pointed to here, whether around production, technologies or marketing, reached its zenith in the 1980s, linked as it was with international investments in agricultural development. Since then, there has been much less empirical work on agrarian issues, especially as international interest in agrarian development interests has moved upstream from the problems of projects to the problems of programme and policy support and to broader questions of governance.

This at a time when realities facing farmers on the continent have radically changed, in the context of new technological, health and global trading challenges, but when their responses to these are nevertheless shaped by similar social relational issues and dilemmas. There is currently a dearth of empirical understanding of these unfolding dynamics. Instead, numerous, heavily funded interventions are being designed according to externally derived theory, based on problematic assumptions about how Africa's farming systems work.

The social issues highlighted in this article are sometimes described, and dismissed, as "microissues", irrelevant to the broad sweep of African farming history and to the monumental plans now deemed necessary to rescue Africa's agriculture. Yet such "small issues" have always been the downfall of grandiose schemes, something which should not be a surprise to those familiar with African literature, whether in its modern guise, or its ancient epics. 


\section{References}

Achebe, C., 1996, Things Fall Apart, London: Heinemann

Amanor, K.S., 1994, The New Frontier: Farmer Responses to Land Degradation, London: Zed Press

Bassett, T., 1993, 'Land Use Conflicts in Pastoral Development in Northern Côte d'Ivoire', in T. Bassett and D. Crummey (eds), Land in African Agrarian Systems, Madison: University of Wisconsin Press: 131-54

Berry, S., 1993, No Condition is Permanent: The Social Dynamics of Agrarian Change in Sub-Saharan Africa, Madison: University of Wisconsin Press

Boserup, E., 1970, Women's Role in Economic Development, London: Earthscan

Brokensha, D., Warren, D. and Werner, O. (eds), 1980, Indigenous Knowledge Systems and Development, Lanham: University Press of America

Chambers, R., Pacey A. and Thrupp, L.-A. (eds), 1989, Farmer First, Farmer Innovation and Agricultural Research, London: IT Publications

de Alcantara, C., 1992, 'Markets in principle and practice', European Journal of Development Research, Vol 4 No 2: 1-16

Dey, J., 1981, 'Gambian women: unequal partners in rice development projects?', Journal of Development Studies, Vol. 17 No 3: 109-22

Fairhead, J., 1992a, 'Indigenous technical knowledge and natural resources management in sub-Saharan Africa: a critical overview', paper prepared for Social Science Research Council project on African Agriculture, Dakar, January

Fairhead, J., 1992b, 'Paths of authority: roads, the state and the market in Eastern Zaire', European Journal of Development Research, Vol 4 No 2: 17-35
Guyer, J., 1986, 'Intra-household processes and farming systems research: perspectives from anthropology', in J. Moock (ed.), Understanding Africa's Rural Households and Farming Systems, Boulder and London: Westview Press: 92-104 Jacobson-Widding, A. and van Beek, W. (eds), 1990, The Creative Communion: African Folk Models of Fertility and the Regeneration of Life, Stockholm: Almqvist \& Wiksell International

Kenyatta, J., 1965, Facing Mt. Kenya: The Tribal Life of the Gikuyu, New York: Vintage Books

Moore, H.L., Sanders, T. and Kaare, B., 1999, Those Who Play With Fire: Gender, Fertility and Transformation in East and Southern Africa, London: Continuum

Newbury, C. and Schoepf, B.G., 1989, 'State, Peasantry, and Agrarian Crisis in Zaire: Does Gender Make a Difference?', in J.L. Parpart and K.A. Staudt (eds), Women and the State in Africa, Boulder, Colorado: Lynne Rienner: 91-110

Richards, P., 1989, 'Agriculture as a Performance', in R. Chambers, A. Pacey and L.-A. Thrupp (eds), Farmer First: Farmer Innovation and Agricultural Research, London: IT Publications

Richards, P., 1986, Coping with Hunger: Hazard and Experiment in an African Rice Farming System, London: Allen and Unwin

Richards, A.I., 1939, Land, Labour and Diet: An Economic Study of the Bemba Tribe, London: Oxford University Press

Scoones, I. (ed.), 2001, Dynamics and Diversity: Soil Fertility and Farming Livelihoods in Africa, London: Earthscan

Shipton, P., 1989, Bitter Money, Washington, D.C.: American Ethnological Society 